\title{
Dampak Pandemi Covid-19 Terhadap Bisnis Online Shop (Baju Anak- Anak) di Kota Serang
}

\author{
Syarif Hidayat \\ Universitas Bina Bangsa Banten, Indonesia \\ email: syarif104577@gmail.com
}

Manuscript History:

Received: 20-09-2021

Accepted: 04-11-2021

Published: 05-11-2021

\begin{abstract}
This study aims to find out and analyze the impact of the COVID-19 pandemic on online shop businesses in the city of Serang. The research method used is descriptive qualitative method, using sources from informants. The process of selecting key informants rolled like a snowball. The research time is March to June 2021. Data collection techniques use field observations, interviews with research objects, and documentation as research supporting materials. The research locus is in Serang City. The results of the study found that the impact of the Covid-19 pandemic on the online shop business was a decline in sales because consumers were now more focused on buying basic necessities and medicines for health.
\end{abstract}

Keywords: pandemic; covid-19; online shop business

\begin{abstract}
Abstrak
Penelitian ini bertujuan untuk mengetahui dan menganalisis seperti apa dampak yang ditimbulkan oleh pandemic covid-19 terhadap bisnis online shop yang ada di kota Serang. Metode penelitian yang digunakan adalah metode kualitatif deskriptif, menggunakan sumber dari informan. Proses pemilihan key informan mengelinding seperti bola salju. Waktu penelitian Maret sampai Juni 2021. Teknik pengumpulan data menggunakan pengamatan dilapangan, wawancara dengan objek penelitian, dan dokumentasi sebagai bahan penunjang penelitian. Lokus penelitian adalah di Kota Serang. Hasil penelitian ditemukan bahwa ada dampak pandemic Covid-19 terhadap bisnis online shop yaitu penurunan penjualan karena konsumen sekarang lebih fokus terhadap pembelian bahan pokok dan obat-obatan untuk Kesehatan.
\end{abstract}

Kata Kunci: pandemi; covid-19; bisnis online shop 
dan pada hari yang sama juga Badan Kesehatan Dunia (WHO) mendeklarasikan bahwa SARCoV2 menjadi nama resmi dari nama penyakit Coronavirus Desease 2019 (COVID-19).

Dibulan Maret 2020 Badan Kesehatan Dunia (WHO) menyatakan bahwa Covid-19 sebagai Pandemi Global di dunia. Menurut (Taufik; Ayuningtyas \& Kusumah, 2020) Covid19 telah menimbulkan economic shock, yang mempengaruhi ekonomi secara perorangan, rumah tangga, perusahaan mikro, kecil, menengah maupun besar, bahkan mempengaruhi ekonomi negara dengan skala cakupan dari lokal, nasional, internasional dan bahkan global (dunia). Dengan penetapan status pandemi covid-19 oleh WHO, maka di berbagai negara di dunia mulai menerapkan lockdown sebagai upaya untuk memutus mata rantai penyebaran covid-19. Semenjak virus covid-19 masuk ke Indonesia, pemerintah menerbitkan peraturan/kebijakan salah satunya pemberlakukan Pembatasan Sosial Berskala Besar (PSBB) dengan tujuan untuk memutus mata rantai penyebaran virus covid-19.

Menurut Juaningsih et al., (2020) Peraturan atau kebijakan ini memiliki efek nyata pada kehidupan masyarakat dimana segala aktivitas sehari-hari menjadi terhambat sehingga masyarakat dituntut untuk bisa melakukan setiap kegiatan atau aktivitas dari rumah dan melalui digitalisasi dalam setiap melakukan kegiatan atau aktivitas sehari- hari seperti Work From Home (WFH) hingga belajar mengajar secara daring/online. (Suswanto \& Setiawati, 2020) menurut (Gu, Han, \& Wang, 2020) Kebijakan itu akhirnya membuat banyak perusahaan, sekolah dan kegiatan yang memerlukan interaksi secara langsung harus di hindari dan menerapkan work from home dan online-learning di setiap kegiatannya. Kebijakan yang di ambil ini memang dipercaya dapat mengurangi risiko cepatnya penularan virus Covid-19 yang telah menyebar di hampir 140 negara di dunia.

Juaningsih et al., (2020) dalam Hadiwardoyo (2020) menyatakan peraturan atau kebijakan PSBB ini harus dilakukan dengan pertimbangan tepat dan benar, hal ini disebabkan dengan pembatasan yang berkepanjangan dapat berisiko besar terkait kemampuan individu dalam menjalankan kehidupannya. Pemberlakuan PSBB tersebut memberikan dampak besar terhadap kehidupan masyarakat baik dari segi ekonomi maupun sosial. Salah satu dampak ekonomi yang dirasakan oleh masyarakat yaitu bisnis online.

Bisnis online adalah serangkaian kegiatan dalam proses jual beli baik berupa barang dan jasa yang dilakukan oleh beberapa pihak, meliputi produsen, distributor, dan konsumen lewat internet. Aktivitas tersebut juga meliputi proses pengenalan produk yang dilakukan melalui kegiatan pemasaran atau promosi digital salah satunya dengan media sosial. Proses ini tidak serta merta terjadi begitu saja. Namun harus melalui proses yang panjang dan membutuhkan waktu yang tidak sebentar dalam menjalaninya.

Untuk dapat terus eksis dalam menjalankan usaha bisnis online tersebut, kita harus bisa memasarkan atau mempromosikan secara kreatif dan inovatif agar mempunyai nilai lebih dimata konsumen atau pelanggan. Serta menjaga kualitas produk yang kita jual sehingga mendapatkan kepercayaan dari para konsumen atau pelanggan. 
Banyak bisnis online yang bermunculan, salah satunya yaitu bisnis online shop baju anakanak di Kota Serang, dimana peneliti tinggal saat ini. Bisnis online shop baju anak-anak merupakan salah satu bisnis yang sangat menjanjikan, karena dapat memberikan pendapatan yang lebih bagi pelaku usahanya dan dapat memberikan kemudahan bagi konsumennya serta harganya pun sangat kompetitif dengan bisnis offline. Efektivitas dan efisiensi itulah yang menjadi dasar dalam bisnis online sehingga semua pelaku usaha maupun konsumen lebih tertarik dalam melakukan aktivitas jual beli secara online

Dengan berdasarkan uraian diatas peneliti tertarik untuk melakukan penelitian dengan judul "EFEK PANDEMI COVID-19 TERHADAP BISNIS ONLINE SHOP (BAJU ANAK-ANAK) DIKOTA SERANG”.

\section{PENGERTIAN BISNIS}

(Republik Indonesia, 2019) Peraturan Pemerintah Republik Indonesia No. 80 Tahun 2019 tentang Perdagangan Melalui Sistem Elektronik yang selanjutnya disingkat PMSE adalah Perdagangan yang transaksinya dilakukan melalui serangkaian perangkat dan prosedur elektronik.

Dalam ilmu ekonomi, bisnis adalah suatu kegiatan individu atau kelompok yang menjual barang atau jasa kepada konsumen dengan tujuan untuk mendapatkan laba atau keuntungan. Secara etimologis, bisnis berarti keadaan di mana seseorang atau sekelompok orang sibuk dalam melakukan suatu pekerjaan untuk mendapatkan keuntungan. Dalam ekonomi kapitalis, dimana kebanyakan bisnis dimiliki oleh pihak swasta, bisnis dibentuk untuk membuat keuntungan dan meningkatkan kemakmuran pemiliknya.

(Stanton, 2020) Menurut Hent dan Urwick, Bisnis online adalah serangkaian kegiatan dalam proses jual beli yang dilakukan oleh beberapa pihak, meliputi produsen, distributor, dan konsumen. Proses ini tidak serta merta terjadi begitu saja. Namun harus melalui proses yang panjang dan membutuhkan waktu yang tidak sebentar. Selain proses jual beli produk, bisnis online menurut Hent dan Urwick juga meliputi kegiatan pelayanan jasa. Jasa yang diberikan harus dapat memenuhi kebutuhan konsumen. Konsumen tersebut bisa dari masyarakat, pemerintah, hingga korporasi atau organisasi.

(Stanton, 2020) Menurut Prof. L.R. Dicksee, Bisnis adalah suatu bentuk aktivitas yang tujuan utamanya untuk memperoleh keuntungan bagi pihak yang mengusahakan atau pihak yang berkepentingan dalam terjadinya suatu bentuk aktivitas tersebut. Dengan kata lain bahwa bisnis dibangun atas tujuan untuk mendapatkan keuntungan dengan melakukan suatu kegiatan atau aktivitas bagi orang orang atau sekolompok orang yang mempunyai kepentingan dalam kegiatan tersebut.

(Stanton, 2020) menurut Hughes dan Kapoor, "Business is an organization that provides goods or services in order toearn provit" artinya Bisnis adalah organisasi yang menyediakan barang atau jasa untuk mendapatkan keuntungan. Sejalan dengan definisi tersebut, aktifitas bisnis melalui penyediaan barang dan jasa bertujuan untuk menghasilkan profit (laba). Suatu perusahaan 
dikatakan menghasilkan profit (laba) apabila total penerimaan pada suatu periode (Total Revenues) lebih besar dari total biaya (Total Costs) pada periode yang sama. Laba merupakan daya tarik utama untuk melakukan kegiatan bisnis, sehingga dengan melalui laba tersebut pelaku bisnis dapat mengembangkan skala usahanya untuk meningkatkan laba yang lebih besar.

Jual beli online di artikan sebagai jual beli barang dan jasa melalui media elektronik, khususnya melalui internet atau secara online. Salah satu contoh adalah penjualan produk secara online melalui internet seperti yang dilakukan oleh bukalapak.com, berniaga.com, tokobagus.com, lazada.com, kaskus, olx.com.

(Fitria, 2017) Menurut Suherman (2002: 179), jual beli via internet yaitu" (sebuah akad jual beli yang dilakukan dengan menggunakan sarana eletronik (internet) baik berupa barang maupun berupa jasa)". Atau jual beli via internet adalah "akad yang disepakati dengan menentukan ciri-ciri tertentu dengan membayar harganya terlebih dahulu sedangkan barangnya diserahkan kemudian" (Urnomo, 2000: 4).

\section{STRATEGI BISNIS}

Menurut (Rosmadi, 2021) Organisasi bisnis (perusahaan) dapat tumbuh dan berkembangan apabila dalam menjalankan aktivitas usahanya berpegang teguh pada konsep efektivitas dan produktivitas. Tanpa konsep tersebut suatu bisnis akan menjadi sulit untuk dijalankan karena terkait dengan profit atau keuntungan perusahaan yang akan didapat selama menjalankan usaha/bisninya Laba atau keuntungan merupakan hal yang sangat didambakan oleh setiap pelaku bisnis dalam melakukan usahanya. Dalam hal ini setiap pelaku bisnis akan berusaha untuk melakukan strategi dalam mendapatkan keuntungan atau laba dalam menjalankan bisnisnya terutama dalam masa pandemic seperti sekarang ini.

(Rosmadi, 2021) Pemasaran produk baik barang maupun jasa dapat memanfaatkan kemajuan teknologi informasi. Media sosial merupakan produk dari teknologi informasi yang tepat seperti sekarang ini sebagai strategi bisnis untuk dapat memberikan manfaat optimal bagi pelaku usaha. Dengan media sosial pelaku usaha dapat memaparkan spesifikasi produk, kualitas, dan harga sehingga konsumen dapat lebih leluasa memilih barang yang dibutuhkan sesuai dengan kemampuannya (Praditya, 2019; Purbohastuti, 2017; Rusdiono, 2019).

(Karambut et al., 2019) Data penetrasi pengguna internet di Indonesia hingga 2017 adalah 143,26 juta jiwa atau 54,68\% dari total penduduk Indonesia yaitu 262 juta jiwa. Penetrasi internet yang berkembang, adopsi perangkat seluler yang cepat, peningkatan penggunaan media sosial dan daya beli yang lebih besar oleh kelas menengah membuat sektor e-commerce Indonesia cepat untuk ekspansi (SP eCommerce 2014; DBS 2015). Penjualan ecommerce (perdagangan elektronik) ritel di Indonesia diperkirakan akan tumbuh 133,5\% menjadi US\$ 16,5 miliar atau sekitar Rp 219 triliun pada 2022 dari posisi 2017 (Asosiasi Penyelenggara Jasa Internet Indonesia, 2017). 
Berdasarkan pengertian di atas bahwa jual beli via internet adalah jual beli yang terjadi dimedia elektronik, yang mana transaksi jual beli tidak mengharuskan penjual dan pembeli bertemu secara langsung atau saling menatap muka secara langsung, dengan menentukan ciriciri, jenis barang, sedangkan untuk harganya dibayar terlebih dahulu baru diserahkan barangnya.

\section{Karakteristik Bisnis Online}

Ada beberapa karakteristik bisnis online, yaitu:
a. Terjadinya transaksi antara dua belah pihak
b. Adanya pertukaran barang, jasa, atau informasi
c. Internet merupakan media utama dalam proses atau mekanisme akad tersebut.

\section{Kelebihan dan Kekurangan Jual Beli Online (Bisnis Online)}

Adapun kelebihan yang di dapat oleh konsumen antara lain:

a. Pembeli tidak perlu mendatangi toko untuk mendapatkan barang, tetapi cukup hanya terkoneksi dengan Internet, kemudian melakukan transaksi seperti memilih barang dan selanjutnya melakukan pemesanan barang, dan barang akan di antar sampai tempat tujuan atau kerumah.

b. Menghemat waktu dan biaya transportasi berbelanja, karena semua barang belanjaan bisa dipesan melalui perantara media internet khususnya situs yang menjual belikan barang yang sesuai dengan kebutuhan atau keinginan para konsumen.

c. Pilihan yang ditawarkan sangat beragam, sehingga sebelum melakukan pemesanan kita dapat membandingkan semua produk dan harga yang ditawarkan oleh penjual.

d. Dengan perantara via internet pembeli dapat membeli barang bukan hanya didalam negeri tetapi juga diluar negeri secara online.

e. Harga yang ditawarkan sangat komfetitif, karena tingkat persaingan dari pelaku usaha melalui media internet (bisnis online) sehingga mereka bersaing untuk menarik perhatian dengan cara menawarkan harga serendah-rendahnya (Sunarto, 2009: 9)

Berdasarkan uraian di atas, maka penulis dapat menyimpulkan bahwa kelebihan jual beli via internet tidak hanya didapatkan oleh konsumen, penjualnya pun mendapatkan keuntunggan dimana penjual tidak perlu mengeluarkan biaya dan susah payah dalam menyewa toko untuk menjual dagangannya, disamping itu penjual dapat memanfaatkan teknologi untuk dapat menjangkau kepada calon pembeli di seluruh dunia, sehingga biaya promosi akan lebih efesien.

Di sisi lain, kelebihan yang mendasar yang ada pada transaksi jual beli via internet ini adalah si pembeli dan penjual sama-sama memiliki kesadaran untuk melakukan kejujuran dan kepercayaan yang tinggi sehingga keduanya tidak pernah merasa dirugikan oleh satu sama lainnya. 
(Fitria, 2017) Menurut, Sofie (2002: 76), disamping kelebihan yang didapat penjual dan pembeli, adapun kelemahanya adalah sebagai berikut:

a. Produk tidak dapat dicoba, dalam jual beli via internet (online), produk yang ditawarkan adalah bermacam-macam dan beragam, dan semua produk tersebut tidak dapat dicoba. Penjual menyediakan jenis ukuran produk yang di pasarkan dan pembeli harus memberikan pertimbangan terhadap ukuran yang tercantum di toko berbasis web tersebut pada saat akan membeli produk.

b. Spesifikasi barang yang ditawarkan terkadang tidak sesuai dengan aslinya. Menurut (Guan \& Oktaviani, 2020) Dalam transaksi online, konsumen tidak dapat melihat barang fisik, tetapi hanya dapat memilih dan membeli sesuai informasi terkait barang yang ditampilkan oleh pelaku bisnis. Bahkan jika pelaku bisnis menampilkan semua informasi produk yang sebenarnya, produk yang ditampilkan oleh gambar masih memiliki kesalahan tertentu dengan produk yang sebenarnya. Ini adalah salah satu kerugian yang di dapat oleh pembeli dalam jual beli via internet, karena kesamaan dari barang dan foto / gambar yang kita lihat disekitar monitor tidak bisa seratus persen persis sama.

c. Terdapat biaya tambahan yaitu biaya pengiriman. Jual beli via internet yang terjadi melalui media elektronik, tentunya pemilik toko online masih memerlukan jasa pengiriman, dan yang menentukan besar dan kecilnya biaya pengiriman produk tersebut adalah salah satunya yaitu jarak yang akan di tempuh oleh perusahaan jasa pengiriman.

d. Risiko penipuan Dalam jual beli via intenet, toko berbasis web rentan akan penipuan. Pastikan sebelum berbelanja di website online, kita harus mengecek akan kredibilitas toko tersebut agar terhindar dari resiko penipuan.

\section{Pengaruh Pandemi Covid-19 terhadap bisnis:}

a. Bisnis startup yang dinilai cukup berat dirasakan oleh para perusahaan startup karena bisnis baru yang dirintis dan belum banyak pelanggan.

b. Terjadi pada berbagai bisnis yang akan kehilangan konsumennya akibat global distancing yang diberlakukan pemerintah karena masyarakat akan lebih berhati-hati dalam membeli barang/jasa.

c. Pengusaha yang memiliki toko-toko offline terpaksa menutup tokonya karena adanya pembatasan-pembatasan aktifitas dan juga global distancing sehingga mereka kehilangan sumber penghasilannya.

d. Para pelaku UMKM mengalami tekanan akibat tidak dapat melakukan kegiatan shingga memenuhi kewajiban kredit terganggu.

e. Pemutusan hubungan kerja diberbagai perusahaan

f. Tempat-tempat pariwisata banyak yang tutup.

g. Menurunnya pendapatan negara dari sektor pajak dll.

h. Ada Sebagian sektor bisnis yang diuntungkan dengan pandemic Vovid-19. 


\section{Strategi Pemasaran Bisnis Online dimasa Pandemi Covid-19:}

a. Buat situs Online Shop

b. Maksimalkan jaringan dan relasi

c. Tambahkan konten marketing yang menarik agar para calon konsumen atau pelanggan menjadi menarik dan penasaran untuk mencoba membeli produk yang kita pasarkan.

d. Maksimalkan penggunaan digital marketing sehingga dapat menjangkau lebih luas calon para konsumen.

e. Miliki target sebagai landasan awal untuk menjalankan sebuah bisnis, seperti target pangsa pasar, target penjualan serta target keuntungan dalam menjalank an bisnisnya.

f. Manfaatkan media sosial marketing dan google Ads untuk pasang iklan secara online. Karena seperti kita ketahui bahwa masyarakat kita sudah mulai banyak menggunakan teknologi digital dalam aktivitas kehidupan sehari hari terutama para melinial.

g. Bergabunglah dengan marketplace agar produk yang kita jual lebih dikenal oleh para konsumen karena marketplace adalah sebagai bentuk perantara yang mengakomodasi antara penjual dan pembeli.

h. Meyakinkan kepada para calon pembeli dengan memberikan informasi akurat terkait produk yang kita jual bahwa produk yang kita jual mempunyai kualitas tinggi sehingga mereka percaya dan akan membelinya. (Melorose et al., 2015) menurut Gefen dan Straub (2004) menyimpulkan bahwa semakin tinggi derajat kepercayaan konsumen, semakin tinggi tingkat pembelian niat konsumen. (Stanton, 2020)

\section{METODE PENELITIAN}

Penelitian ini bertujuan untuk mengetahui dan menganalisis seperti apa dampak yang ditimbulkan oleh pandemic covid-19 terhadap bisnis online shop yang ada di kota Serang. Metode penelitian yang digunakan adalah metode kualitatif deskriptif, menggunakan sumber dari informan. Proses pemilihan key informan mengelinding seperti bola salju. Waktu penelitian Maret sampai Juni 2021. Teknik pengumpulan data menggunakan pengamatan dilapangan, wawancara dengan objek penelitian, dan dokumentasi sebagai bahan penunjang penelitian.

\section{HASIL PENELITIAN DAN PEMBAHASAN}

Kota Serang merupakan salah satu kota besar dengan perkembangan ekonomi yang begitu pesat. Berbagai peluang usaha bisa kita jalankan di Kawasan kota Serang. Kota serang adalah ibukota provinsi Banten yang letak geografisnya dekat dengan ibukota negara. Karena termasuk ibukota provinsi, peluang usahanya juga memiliki pilihan lebih banyak. Tak hanya menyasar sektor kebutuhan, peluang bisnis tersebut juga menyasar ke sektor gaya hidup dan pemenuhan kebutuhan sekunder lainnya, baik usaha berbasis offline maupun online.

Usaha bisnis yang sekarang banyak diminati dan berkembang yaitu usaha bisnis online. Bisnis online ini menjadi trend tersendiri bagi masyarakat luas terutama masyarakat 
perkotaan. Bisnis online diyakini dapat membawa perubahan pola pikir serta mindset para pelakunya, baik produsen/pejual maupun konsumen/pembeli dalam menjalankan aktivitas/kegiatan transaksi bisnisnya. Perubahan pola pikir dan mindset ini menjadi tolak ukur para pelaku usahanya, karena bisnis online adalah transaksi antara penjual dan pembeli dimana keduanya tidak saling bertemu. Apalagi para pembeli/konsumen tidak bisa mencoba barang yang akan dibelinya, tetapi mereka saling mempercayainya.

Kepercayaan ini harus dibangun diantara keduanya baik penjual maupun pembelinya, terutama untuk para penjual karena mereka dituntut secara professional dalam melakukan bisnis onlinenya. Dengan kata lain bahwa para penjual bisnis online harus memberikan informasi terkait barang yang akan dijualnya secara transparan dan akurat. Informasi yang di sampaikan penjual adalah suatu bentuk informasi penting yang akan diterima oleh calon pembeli / konsumen yang mana apabila informasinya sesuai dengan kenyataan, maka ini akan menjadikan nilai tersendiri bagi para calon pembeli/konsumen terhadap para penjual. Dengan begitu maka terciptalah suatu hubungan yang akan melahirkan kepercayaan dalam berbisnis.

Bisnis online adalah bisnis yang berbasis jaringan internet dimana semua aktivitas dilakukan didunia maya. Para pelaku bisnis online tidak terbatas oleh waktu dan tempat dalam berbisnis. Kapan dan dimana pun bisa melakukan transaksi bisnis, bisa dikatakan bahwa bisnis online lebih fleksibel dalam menjalankan bisnisnya. Bisnis online banyak menggunakan produk teknologi yangh berbasis internet seperti media sosial seperti: whatsapp, facebook, Instagram dll.

Para pakar menyetujui, bahwa dengan adanya media sosial sebagai salah satu media untuk memasarkan hasil produksi telah memberikan manfaat dan pengetahuan serta informasi penting kepada para konsumen berkaitan dengan spesifikasi produk yang akan mereka beli (Widyaningrum, 2016; Singh, Jackson, \& Cullinane, 2008; Mongold \& Faulds, 2009). Kondisi ini harus didukung oleh data-data yang jelas, jujur, dan terpercaya sehingga konsumen tidak dirugikan dalam melakukan transaksi meskipun melalui media sosial. Selain itu kepercayaan pada perusahaan serta harga yang kompetitif menjadi alternatif terbaik bagi konsumen (Nasution \& Yasin, 2014; Siagian \& Cahyono, 2014; Ganguly, Dash, Cyr, \& Head, 2010).

Menurut (Rosmadi, 2021) Hasil penelitian empiris yang dilakukan oleh Grandon \& Pearson (2004), Orapin (2009), dan Kurniawan (2017) dapat disimpulkan, bahwa e-business atau e- commerce sangat berguna dan bermanfaat baik bagi produsen yang memiliki produk maupun konsumen yang membutuhkan produk dengan cepat, tepat, dan sesuai dengan yang diharapkan.

Ketertarikan bagi para konsumen untuk memiliki suatu jenis produk ditentukan oleh beberapa faktor, diantaranya yaitu: kualitas produk, spesifikasi produk, dan harga produk itu sendiri. Seiring dengan berkembangnya ilmu pengetahuan dan teknologi informasi bebasis internet, maka para konsumen sangat dimudahkan dengan adanya internet yang mampu menyediakan segala informasi dan kebutuhan manusia terkait dengan produk yang mereka inginkan. Dengan kata lain bahwa teknologi informasi sangat membantu dalam kehidupan 
manusia dalam berbagai kegiatan/aktivitas sehari hari. Didalam dunia bisnis teknologi informasi menjadi salah satu strategi bisnis.

(Rosmadi, 2021) Strategi bisnis yang tepat untuk memasarkan produk di masa pandemi covid-19 seperti sekarang ini adalah melalui media elektronik dimana antara produsen dan konsumen tidak bertemu langsung pada satu tempat tetapi memiliki jangkauan pemasaran yang sangat luas (Ulya, 2020; Riyadi, Mahkota, \& Suyadi, 2014; Kaplan, 2012).

Dari hasil penelitian empiris yang dilakukan oleh Bastian (2015), Jermias (2008), dan O’Brien (2003) dapat disimpulkan, bahwa pemanfaatan teknologi informasi melalui sosial media merupakan strategi yang tepat untuk memasarkan hasil produksi tanpa batas dengan tetap memperhatikan neraca keuangan perusahaan. Hal ini tentunya memperkuat pendapat (Rosmadi, 2021) dari Suswanto \& Setiawati (2020), Gu, Han, \& Wang (2020) yang menyatakan bahwa pemasaran produk secara online sangatlah tepat dalam upaya mendukung pemasaran secara tradisional.

Hasil penelitian yang dilakukan pada bisnis online shop bahwa untuk dapat bertahan dan tetap eksis dalam menjalankan bisnis online menurut ibu Dewi Yuliana selaku pemilik bisnis online Arkaan shop (bisnis baju anak-anak) diperumahan griya permata asri kota Serang bahwa harus memaksimalkan dalam memasarkan produknya dengan internet yaitu media sosial seperti: whatsapp, facebook dan instagram dan harus tetap mempertahankan kualitas produk yang dijual sesuai dengan informasi serta memberikan pelayanan yang optimal kepada para pelanggannya.agar produk yang kita jual mempunyai nilai yang tinggi bahkan lebih tinggi dari harapan para pelanggan atau konsumen. Hal ini dapat dilihat pada gambar berikut :
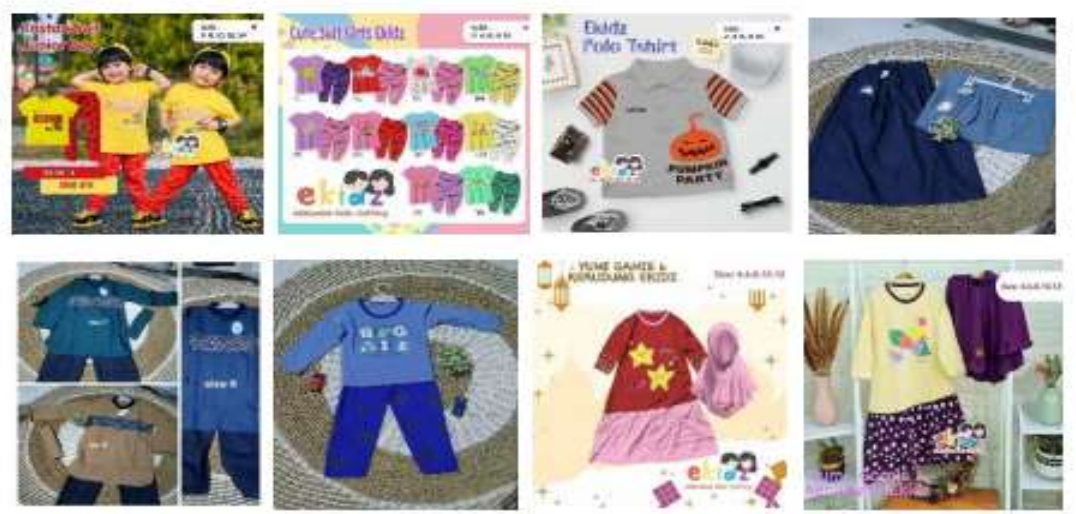

Sumber: Arkaan Shop, 2021: data diolah

Dari gambar di atas dapat dijelaskan bahwa Arkaan shop sudah memasarkan baju anakanak melelui internet dengan memanfaatkan media sosial seperti whatsapp, facebook, dan instagram, sebagai salah satu strategi dalam menjalankan usahanya ditengah tengah pandemic covid-19. Cara ini dinilai sangat efektif dan effisien serta tepat karena di tengah pandemi covid-19 segala sesuatunya dikerjakan tanpa bersentuhan secara langsung (menjaga jarak) untuk memutus penyebaran virus covid-19. 
Data di atas menunjukkan bahwa pemanfaatan internet dan media sosial sebagai bagian dari strategi pemasaran bisnis online sudah sangat tepat apalagi di saat pandemi covid-19 seperti sekarang ini. (Republik Indonesia, 2019) Peraturan Pemerintah Republik Indonesia nomor 80 Tahun 2019 Tentang perdagangan melalui system elektronik bahwa Iklan Elektronik adalah informasi untuk kepentingan komersial atas Barang dan/atau Jasa melalui Komunikasi Elektronik yang dimuat dan disebarluaskan kepada pihak tertentu baik yang dilakukan secara berbayar maupun yang tidak berbayar.

Dengan demikian penulis dapat menyimpulkan bahwa penerapan strategi yang tepat selain dapat mempertahankan kelangsungan usaha juga dapat memperluas jaringan pemasaran yang berdampak positif bagi pertumbuhan dan perkembangan usaha kecil di masa yang akan datang.

Dari hasil wawancara dengan pemilik bisnis online Arkaan shop yaitu Ibu Dewi Yuliana diketahui bahwa pemanfaatan internet dan media sosial untuk memasarkan bisnisnya sangat efektif dan effisien serta tepat dan bermanfaat bagi kelangsungan usahanya agar tetap eksis walaupun ditengah pandemic covid-19 seperti sekarang ini. Strategi bisnis yang digunakan oleh Ibu Dewi Yuliana yang dalam masa pandemic covid-19 ini antara lain melalui Whatsapp, Instagram, Facebook.

Saat ini iklan atau pemasaran sangat penting agar pembeli bisa melihat produk-produk yang dijual oleh pemilik usaha bisnis online. Iklan adalah promosi, pariwara atau penyebaran infromasi mengenai produk, baik berbentuk barang ataupun jasa. Advertising juga diartik an sebagain pesan atau berita yang ada dalam berbagai bentuk dan sebagai media yang mana sengaja dibuat untuk menginformasikan dan mengenalkan suatu produk atau jasa kepada khalayak ramai untuk diketahui dan agar para pembeli atau pelanggan tertarik untuk melakukan transaksi pembelian terkait barang yang di sukainya.advertisement juga sering diistilahkan sebagai sebuah ujung yang sangat penting untuk memburu buruan, yang mana dalam hal ini adalah masyarakat luas. Di bisnis, iklan merupakan hal yang sangat penting untuk keberlangsungan suatu bisnis. Suatu produk tidak akan bisa dikenal oleh masyarakat luas tanpa iklan.

\section{Cara beradvertisement yang baik}

Sebagai seorang pebisnis memang sebaiknya memahami strateginya bagaimana cara membuat iklan yang bisa direspon dari banyak calon pembeli. Sangat disayangkan apabila telah habis-habisan mengeluarkan banyak biaya untuk beriklan akan tetapi tidak mendapat feedback sama sekali dari pembaca yang anda targetkan, salah satu faktornya mungkin di sebabkan cara beriklan anda yang kurang menarik bagi calon pembeli.

Terdapat 5 strategi cara beriklan produk agar banyak direspon oleh calon pembeli yang telah anda target, diantaranya yakni:

a. Memakai Kata-Kata yang Poweful dan Menarik. 
Kata-Kata yang Menarik dan Powerful ialah salah satu dari strategi beriklan yang sangat efektif sekali dalam dunia pemasaran produk di berbagai media. Kalimat yang menarik ialah kalimat yang mampu menggaet perhatian sehingga pembaca tertarik untuk terus melanjutkan membaca tulisan iklan anda. Apabila berupa banner di situs online mampu membuat pembaca tertarik mengklik dan menuju ke toko online anda, gunakan selogan yang menarik, atau dengan bahasa yang memancing rasa penasaran konsumen untuk lebih tahu secara lebih dalam.

b. Memakai Foto Orang Terkenal.

Strategi beriklan satu ini cukup memukau apabila diterapkan dalam beriklan, Karena ini membutuhkan biaya dana yang tidak sedikit.

c. Fokus kepada detail dalam Iklan.

Ketika membuat iklan anda harus memperhatikan juga hal-hal kecil yang berkaitan dengan Bahasa yang digunakan dalam membuat iklan.

d. Masukkan Testimoni

Kalau anda beriklan jika sudah memiliki konsumen user produk kalian, maka mintalah mereka untuk memberikan testimony atau pendapat terkait dengan kepuasan terhadap produk dan layanan bisnis anda.

e. Menunjukkan Kelebihan Produk Kamu

Saat proses pembuatan iklan atau beriklan anda tambahkan juga kelebihan ataupun keunggulan produk anda, hal ini akan sangat menarik perhatian para konsumen untuk melakukan transaksi pembelian.

\section{Ciri-ciri Iklan:}

a. Menggunakan pilihan kata yang tepat dan menarik

Ciri utama iklan dapat dilihat dalam penggunaan kata-katanya. Iklan yang baik menggunakan kata-kata yang tepat dan menarik, sehingga mudah diingat oleh masyarakat.

b. Menjelaskan produk yang diiklankan

c. Menonjolkan informasi utama

Ciri iklan berikutnya adalah menonjolkan informasi utama yang dipentingkan. Informasi ini menjadi pusat perhatian utama dari iklan sehingga ditonjolkan, bisa dengan ukurannya lebih besar atau warna yang berbeda dari yang lainnya.

d. Pesan disampaikan secara komunikatif dan informatif

Maksudnya pesan dalam iklan mampu diinformasikan dengan baik pada masyarakat luas, dengan cara-cara komunikasi dengan baik sehingga pesannya tersampaikan dengan tepat. 
e. Menggunakan kata-kata persuasif

Iklan bertujuan untuk membujuk masyarakat atau target pasar agar membeli atau menggunakan produk yang diiklankan. Untuk itu diperlukan bahasa persuasif untuk mencapai tujuan tersebut.

f. Sesuai dengan sasaran

Iklan yang baik tentu sudah disesuaikan dengan sasaran atau target pasarnya. Misalnya jika target pasar produk adalah kalangan milenial, maka harus membuat iklan yang unik dan kreatif agara informasi dan pesan bisa diterima oleh target pasarnya.

g. Memadukan unsur kata dan gambar

Iklan yang baik memadukan berbagai unsur-unsur, seperti gambar dan kata-kata. Iklan yang hanya berisi kata-kata tentu membosankan sehingga perlu dipadukan dengan gambar dan grafis yang bagus. Jika berbentuk video, bisa dipadukan juga dengan unsur suara atau music dan unsur gerak.

h. Menarik Perhatian

Ciri-ciri iklan yang terakhir adalah iklan harus bisa menarik perhatian. Iklan yang baik harus mampu menarik perhatian target konsumen, sehingga produk yang diiklankan bisa diketahui dan diingat-ingat oleh khalayak ramai.

\section{6 Cara Membuat Iklan yang Efektif:}
a. Ciptakan Elemen Kreatif
b. Berikan Penawaran Menarik.
c. Bicarakan Tentang Manfaat yang Akan Diperoleh.
d. Beri Alasan untuk Membeli Sekarang.
e. Gunakan Testimonial.

Bangun Mindest Bisnis Online dengan benar. Perlu diketahui jika fokus penentu kesuksesan sebuah bisnis sebagian besar ditentukan karena kualitas pribadi dari manusianya. Ini adalah hal-hal yang sifatnya non teknis, dan sisanya merupakan yang bersifat teknis. Anda bisa saja memiliki banyak keahlian yang terbaik dalam suatu bidang, namun jika anda tidak memiliki visi terhadap skill yang anda miliki maupun tidak terus mau belajar, bisnis yang anda jalani tidak akan maju. Anda harus bisa menangkap bagaimana peluang yang ada di pasaran sebelum akhirnya akan menjual produk tersebut secara online. Yang terpenting dalam membangun usaha, baik online atau tidak adalah dari niat yang anda miliki. Jika anda berusaha dengan keras dan sungguh-sungguh, bukan tidak mungkin jika usaha yang anda jalani akan 
sukses dan mendatangkan untung besar. Jadi bukan hal yang tidak mungkin bagi seorang Ibu rumah tangga untuk mendapatkan banyak uang meskipun hanya dari rumah sekalipun.

\section{KESIMPULAN}

Di tengah pandemi Covid-19 ini, tentunya banyak masyarakat yang mengalami kemacetan masalah keuangan, karena saat pandemi Covid-19 kegiatan ekonomi mengalami kendala atau kemacetan salah satunya bisnis online yang ada di kota Serang.

Di kota serang terdapat banyak bisnis online yang menjual berbagai macam produk salah satunya yaitu Arkaan shop yang menjual baju anak-anak, dan pemilik bisnis online tersebut yaitu ibu Dewi Yuliana melakukan pemasaran melalui media sosial, seperti Instragam, Whatsapp dan Facebook.

Menurut ibu Dewi Yuliana selaku pemilik bisnis online baju anak-anak diperumahan griya permata asri, pandemi ini sangat berpengaruh terhadap bisnisnya, yang biasanya penjualan sehari-hari bisa mencapai puluhan baju anak-anak terjual, dimasa pandemi ini ada penurunan karena konsumen sekarang lebih fokus terhadap pembelian bahan pokok dan obat-obatan untuk kesehatan.

Selain lebih fokus kepada bahan pokok dan obat-obatan kesehatan, faktor finansial dalam era pandemi ini juga menjadi bahan pertimbangan bagi pelanggan untuk lebih memikirkan apa yang menjadi prioritasnya dalam masa sekarang. Tetapi, tidak menutup kemungkinan untuk konsumen berbelanja di toko online, hanya saja peminatnya tidak sebanyak ketika membuka toko offline store.

Walaupun penurunan peminatnya tidak begitu signifikan karena sudah ada pelanggan tetap yang sering membeli ditoko online shopnya, tetap saja berpengaruh terhadap pendapatannya. Beberapa orang berpikir belanja melalui online membuat kita tidak mengetahui kondisi dari barang tersebut dan yang lebih membuat tidak hematnya yaitu mengeluarkan biaya karena adanya biaya ongkos kirim yang lebih mahal dibandingkan barang dagangan. Berbeda ketika berbelanja melalui offline store, kita bisa melihat kondisi barang tersebut secara langsung apakah ada kekurangan dari barang tersebut dan yang terpenting tida menggunakan ongkos kirim untuk belanja barang tersebut.

\section{DAFTAR PUSTAKA}

Fitria, T. N. (2017). Bisnis Jual Beli Online (Online Shop) Dalam Hukum Islam Dan Hukum Negara. Jurnal Ilmiah Ekonomi Islam, 3(01), 52. https://doi.org/10.29040/jiei.v3i01.99

Guan, Y., \& Oktaviani, E. (2020). Landasan Teori Hukum Hak Pengembalian Barang Tanpa Alasan Dalam E-commerce. Iuris Studia: Jurnal Kajian Hukum, 1(2), 162-169.

Juaningsih, I. N., Consuello, Y., Tarmidzi, A., \& NurIrfan, D. (2020). Optimalisasi Kebijakan Pemerintah dalam penanganan Covid-19 terhadap Masyarakat Indonesia. SALAM: Jurnal Sosial Dan Budaya Syar-I, 7(6), 509-518. 
https://doi.org/10.15408/sjsbs.v7i6.15363

Karambut, F., . H., Nurmalina, R., \& Najib, M. (2019). Efek Faktor Demografi Dan Karakteristik Bisnis Online Terhadap Minat Pengajuan Kredit Mikro. Mix: Jurnal Ilmiah Manajemen, 9(1), 141. https://doi.org/10.22441/mix.2019.v9i1.009

Melorose, J., Perroy, R., \& Careas, S. (2015). TRUST AND TAM IN ONLINE SHOPPING: AN INTEGRATED MODEL1 By: Statewide Agricultural Land Use Baseline 2015, 1(1), $51-90$.

Republik Indonesia. (2019). Regulation of The Government No.80 of 2019. Government Regulation, 80(019092), 61.

Rosmadi, M. L. N. (2021). Penerapan Strategi Bisnis di Masa Pandemi Covid-19 Jurnal IKRAITH Ekonomika Vol 4 No 1 Bulan Maret 2021. Jurnal IKRA-ITH Ekonomika, 4(1), $122-127$.

Stanton. (2020). Strategi Marketing Bisnis di Masa Pandemi Covid-19. 46.

Suswanto, P., \& Setiawati, S. D. (2020). Strategi Komunikasi Pemasaran Shopee Dalam Membangun Positioning Di Tengah Pandemi Covid-19 Di Indonesia. Jurnal Imu Komunikasi, 3(2), 16-29. http://52.221.78.156/index.php/linimasa/article/view/2754

Taufik; Ayuningtyas, \& Kusumah, J. R. (2020). The Impact of Covid-19 Pandemic on Business and Online Platform Existance. Jurnal Ilmu Manajemen Terapan (JIMT), 22(5), $21-32$. 